\title{
Peran Perempuan Sebagai Buruh Harian Lepas Dalam Meningkatkan Kesejahteraan Keluarga (Studi Kasus Perempuan Buruh Harian Lepas Desa Tiyingtali, Kecamatan Abang, Kabupaten Karangasem)
}

\author{
Ni Wayan Widnyani*1, Kadek Rai Suwena ${ }^{2}$ \\ 1,2Program Studi Pendidikan Ekonomi \\ Universitas Pendidikan Ganesha \\ Singaraja, Indonesia
}

Riwayat Artike Tanggal diajukan: 29 Juni 2021

Tanggal diterima : 23 November 2021

Tanggal dipublikasikan 15 Desember 2021

Pengutipan: Widnyani, N,W.\& Suwena, K, R. (2021). Peran Perempuan Sebagai Buruh Harian Lepas Dalam

Meningkatkan Kesejahteraan Keluarga (Studi Kasus

Perempuan

Buruh Harian Lepas Desa

Tiyingtali,Kecama tan Abang,

Kabupaten

Karangasem).

Jurnal Pendidikan

Ekonomi

Undiksha,

13(2),357-364

http://dx.doi.org/1 $0.23887 /$ ijpe.v13i 2.36227 e-mail: widnyaniwayan79@gmail.com¹,rai.suwena@undiksha.ac,id²

Tujuan dari penelitian ini yaitu untuk mengetahui peran perempuan sebagai buruh harian lepas dalam meningkatkan kesejahteraan keluarga di Desa Tiyingtali, Kecamatan Abang, Kabupaten Karangasem. Jenis penelitian ini yaitu penelitian kualitatif dengan metoda studi kasus. Subjek dari penelitian ini menggunakan 5 orang informan dan objeknya adalah perempuan yang bekerja sebagai buruh harian lepas di Desa Tiyingtali. Metoda pengumpulan data dilakukan dengan observasi awal, wawancara mendalam terhadap informan dan dokumentasi. Teknik analisis data yang digunakan dalam penelitian ini adalah analisis kualitatif dari Miles dan Huberman yaitu dimulai dari pengumpulan data, mereduksi data, menyajikan data dan menarik kesimpulan. Teknik keabsahan data dalam penelitian ini mengggunakan triangulasi sumber. Hasil penelitian menunjukkan bahwa perempuan buruh harian lepas membagi waktunya dengan mengutamakan perannya sebagai ibu rumah tangga terlebih dahulu dan melanjutkan perannya di sektor publik sebagai pekerja informal yaitu buruh harian lepas dan keluarga dari perempuan pekerja buruh harian lepas sudah dinyatakan sejahtera dengan tingkat kesejahteran keluarga berada pada tahapan keluarga sejahtera I.

Kata kunci: Perempuan; Buruh Harian Lepas; Kesejahteraan Keluarga

Abstract
The purpose of this study is to determine the role of women as casual daily laborers
in improving family welfare in Tiyingtali Village, Abang District, Karangasem
Regency. This type of research is qualitative research with case study method. The
subjects of this study used 5 informants and the object was women who worked as
casual daily laborers in Tiyingtali Village. The data collection method was carried
out by initial observation, studying the informants and documentation. The data
analysis technique used in this study is a qualitative analysis from Miles and
Huberman, starting from collecting data, reducing data, presenting data and
drawing conclusions. The data validity technique in this study uses source
triangulation. The results showed that women daily casual workers divide their time
by prioritizing as housewives first and continue working in the public sector as
informal workers, namely casual daily workers and the families of women daily
workers have been declared prosperous with a family welfare level of at prosperous
family l.

Keywords : Woman; Freelance; Family Welfare 


\section{PENDAHULUAN}

Tiyingtali merupakan desa yang berada di Kecamatan Abang, Kabupaten Karangasem dengan lokasinya yang berada didataran rendah. Secara umum jumlah penduduk di Desa Tiyingtali adalah sebanyak 4.548 orang. 2.267 orang untuk jumlah penduduk laki-laki dan 2.281 orang untuk jumlah penduduk perempuan. Berdasarkan ovservasi awal yang di lakukan data yang di temukan di lapangan tepatnya di Desa Tiyingtali terdapat perempuan yang memiliki keterbatasan pendidikan dan keterampilan memilih bekerja sebagai buruh harian lepas. Melalui survey yang dilakukan terdapat 8 banjar yang ada di Desa Tiyingtali, dari masing-masing banjar terdapat jumlah perempuan yang bekerja sebagai buruh harian lepas (1) Banjar Dinas Celuk terdapat 52 orang perempuan sebagai buruh harian lepas; (2) Banjar Dinas Tiyingtali Kaler terdapat 27 orang perempuan buruh harian lepas; (3) Banjar Dinas Tiyingtali Kelod terdapat 27 orang perempuan sebagai buruh harian lepas; (4) Banjar Dinas Kertewarah Kawan terdapat 3 orang perempuan sebagai buruh harian lepas; (5) Banjar Dinas Kertewarah Kangin terdapat 31 orang perempuan sebagai buruh harian lepas; (6) Banjar Dinas Gamongan terdapat 11 orang perempuan sebagai buruh harian lepas; (7) Banjar Dinas Tumingal terdapat 31 orang perempuan sebagai buruh harian lepas; (8) Banjar Dinas Tauka terdapat 34 orang perempuan sebagai buruh harian lepas; untuk seluruh jumlah perempuan buruh harian lepas yang ada di Desa Tiyingtali adalah sebanyak 216 orang. Untuk menyambung hidupnya perempuan di Desa Tiyingtali yang mengambil pekerjaan sebagai buruh harian lepas merupakan solusi bagi mereka, yang mengandalkan tubuh atau fisiknya dalam bekerja.

Aktivitas sehari-hari penduduk di Desa Tiyingtali memiliki mata pencaharian yang berbeda-beda dapat dilihat dari data yang diperoleh yang menunjukkan bahwa pekerjaan dari penduduk desa meliputi (1) petani sebanyak 669 orang; (2) usaha ternak sebanyak 500 orang; (3) PNS sebanyak 12 orang; (4) pedagang barang kelontong sebanyak 23 orang; (5) nelayan sebanyak 1 orang; (6) perawat swasta sebanyak 6 orang; (7) bidan swasta sebanyak 4 orang; (8) TNI \& POLRI sebanyak 27 orang; (9) guru swasta sebanyak 24 orang; (10) dosen swasta sebanyak 2 orang; (11) pedagang 142 orang; (12) jasa konsultasi manajemen dan teknis 1 orang; (13) karyawan perusahaan swasta sebanyak 521 dan perusahaan pemerintah sebanyak 57 orang (14) kontraktor sebanyak 1 orang; (15) sopir sebanyak 2 orang; (16) tidak mempunyai pekerjaan tetap sebanyak 173 orang.

Dari 16 jenis pekerjaan yang ada di Desa Tiyingtali masih banyak ditemukan kondisi keluarga lebih dominan berada pada tahapan keluarga sejahtera I, dari data yang di peroleh dengan jumlah kepala keluarga sebanyak 1.258 terdapat 1.116 keluarga yang berada pada tahapan keluarga sejahtera I. BKKBN menyatakan bahwasanya terdapat 5 tingkatan kesejahteraan meliputi: (1) keluarga prasejahtera; (2) keluarga sejahtera I; (3) keluarga sejahtera II; (4) keluarga sejahtera III; (5) keluarga sejahtera III Plus. Konsepsi Kesejahteraan tidak bisa terpisahkan pada segi keluarga miskin. Sementara Rostiana, dkk (2018:2) menyatakan keluarga sejahtera sebagai keluarga yang tidakmiskin. Karenanya, pengertian serta ukuran derajad kesejahteraan mempunyai hubungan terhadap pengertian dan ukuran derajad kemiskinan.

Menurut Robert Zoellick (2007) dalam Todaro \& Smith (2018) masyarakat yang paling menderita adalah kaum miskin pedesaan, perempuan di negara berkembang dan perkembangan kehidupan anak-anak. Todaro \& Smith (2018) menyatakan bahwa kehidupan masyarakat di negara berkembang ditanggulangi kekurangan yang tersebar dan ketidakseimbangan penghasilan yang makin meningkat yaitu bagian daripada semua masalah ekonomi pembanguna. Selain kekurangan ekonomi serta ketimpangan yang tersebar di negara berkembang adapun permaslahan lainya yang memiliki kesamaan dalam pentingnya dan bisa semakin krusial ialah permasalahan ketidakseimbangan kekuatan, keadaan, gender, puas terhadap pekerjaan, keadaan 
pekerjaan, taraf kesertaan, pengecualian melakukan pemilihan, dan beberapa ukuran permasalahan yang lain.

Di lihat dari masyarakat menengah ke bawah laki-laki sekaligus sebagai kepala rumah tangga dengan penghasilan yang sangat rendah mengakibatkan kurang terpenuhinya keperluan utam. Masalah ini dapat berpengaruh terhadap kesejahteraan keluarga. Upaya menanggulangi masalah itu, dominan yang terjadi pada kaum perempuan ikut serta mengerjakan sesuatu guna menolong suami untuk menambah pendapatan ekonomi. Menurut Clara (2020) menyatakan bahwa alokasi kerja (Division of Labour) biasanya masyarakat memisahkan kerjaan didalam rumah tangga berdasar jenis kelamin. Namun implemantasi pada setiap masyarakat tentunya tidak sama. Misalnya di Baku perempuan kerap bersangkutan secara giat melakukan kerjaan dimana masyarakat jawa dinilai seperti kerjaan laki-laki.Umumnya bagi perempuan kondisi keluarga menengah ke bawah mendapatkan kesempatan untuk mewujudkan potensinya melalui pekerjaan di sektor informal.

Menurut ILO (International Labour Organisation) dalam Yuningsih (2017) menyatakan bahwa pekerjaan di dibidang non-formal ialah sekumpulan tipe kerjaan yang membuahkan penghasilan yang tidak menetap, tidak terlalu mengutamakan keselamatan dalam bekerja, lokasi kerja yang tanpa memiliki keadaan menetap terkait profesi mereka juga satuan usaha atau badan yang tidak memilki hukum. Karakteristi aktivitas bidang informal yakni memilki kemudahan dalam masuk, termasuk anak-anak. Tiap individu bisa masuk dalam ke golongan usaha informal kapanpun, berpaut dalam sumber daya setempat. Umumnya, bisnis yang dimiliki keluarga, pengoperasiannya pada skala yang rendah, singkat karya, ketangkasan didapat dari external jaringan formal sekolah dan tanpat aturan, dan persaingan pasar.

Pendidikan dan keterampilan rendah yang membuat perempuan memilih sebagai pekerja di sektor informal dengan memilih buruh harian lepas sebagai bentuk kontribusi dalam membantu memenuhi kebutuhan dengan harapan dapat membantu melanjutkan kesejahteraan keluarganya. Pekerjaan sektor informal yaitu buruh harian lepas sudah diatur oleh peraturan KEPMEN No. 100 Tahun 2004 Pasal 10, dinyatakan bahwasanya dalam mengambil pekerjaan khusus yang mengalami perubahan berkaitan dengan periode dan kapasitas pekerjaan dan juga pengupahan di hitung berdasar kedatangan, bisa di lakukan melalui kesepakatan dalam bekerja perhari yang di laksanakan melalui ketuntasan buruh sedikit dari 21 hari didalam satu bulan.

Fakta ini menjadikan perempuan mempunyai dua peranan secara bersmaan, yaitu tugas domestik yang memiliki tugas mengurusi rumah tangganya dan perannya di publik sebagai perempuan pekerja untuk memenuhi kebutuhan hidup seluruh keluarganya. Menurut Todaro \& Smith (2018) pengembangan biasanya memeriksa bahwasanya perempuan mempunyai peranan tepenting didalam pembangunan. Tetapi nyatanya memperlihatkan bahwasanya perempuan di anggap memiliki kemiskinan yang lebih tinggi jika di bandingkan dengan laki-laki. Maka tidak jarang terjadi konflik atau kekerasan keluarga yang dialami oleh perempuan atau istri yang sudah berkeluarga mengenai dua peran yang di lakukannya demi mensejahterakan keluarga. Seperti halnya pengakuan bagi perempuan yang memiliki dua peran dalam keluarga masih sangat kurang dan bahkan masih sering di anggap lebih di bawah dari pada laki-laki Puspitawati (2019).

Puspitawati (2012) menyatakan bahwa banyak di temui adanya batasan norma dan adat penduduk kepada perlakuan perempuan, biasanya di awali pelebelan atau stereotype dan/atau subordinasi (penomorduaan) kepada perempuan. Marginalisasi pada perempuan diantaranya berasal dari kebiasaan dan adat istiadat, dan juga bisa berasal dari kearifan pemerintah dan kepercayaan. Ketidak samaan peranan gender yang di akibatkan oleh arti budaya masyarakat ini yang mengadakan ketidak-adilan gender terkhusus untuk para perempuan. 
Ketergantungan diperlihatkan keluarga.

perempuan pun didalam penghidupan

Laki-laki memiliki tugas yang di tempatkan sebagai penanggung keluarga dan sebagai seorang yang memimpin serta mencarikan nafkah untuk keluarga, dengan begitu dapat membuat laki-laki selaku mengambil pendapat yang terutama didalam keluarga dan dalam hidup bermasyarakat. Tugas perempuan selaku ibu rumah tangga dan istri menjadikan di belakang naungan suaminya. Ketergantungan ini mengakibatkan kedudukan perempuan masih terpinggirkan walaupun telah terjadnyai kenaikan penghasilan para perempuan yang melampaui suaminya, namun masih saja di berikan label bahwasanya apa yang sosok perempuan hasilkan semata-mata sebagai tambahan atau sampingan didalam mencukupi keperluan keluarganya (Puspitawati, 2012).

Secara berkelanjutan rancu dan memjadikan kekeliruan dalam mengartikan jenis kelamindan kodrat wajib diluruskan dengan sesegera mungkin. Gender yang dibicarakan terkait ketidaksamaan tugas atau pekerjaan antar perempuan dan lakilaki yang di terbentuk dari masyarakat atau kebudayaan semenjak seseorang dilahirkan dan bukan dijadikan kodrat. Gender tidak saja berbicara terkait perempuan semata, tetapi berbicara juga terkait laki-laki didalam hubungannya dengan kolaborasi dan pembagian tugas antar perempuan dan laki-laki dalam tercapainya target yang ditentukan. Sementara jenis kelamin umumnya dipakai untuk mengenali ketidaksamaan perempuan dan laki-laki dari aspek anatomi biologi yang sudah menjadikan kodrati. (Puspitawati, 2019).

Akibat kerancuan ini, masih banyak masyarakat menganggap bahwa peran gender bersifat kodrati, khususnya untuk kaum perempuan. Untuk mengatasi masalah ini perempuan harus dihargai dan memiliki tempat di masyarakat serta memiliki nilai lebih di pandangan keluarga khususnya laki-laki. Dari pemaparan latar belakang peneliti tertarik untuk melakukan penelitian mengenai "Peran Perempuan sebagai Buruh Harian Lepas dalam meningkatkan Kesejahteraan Keluarga (Studi Kasus: Perempuan Buruh Harian Lepas Desa Tiyingtali, Kecamatan Abang, Kabupaten Karangasem)"

\section{Metode}

Penelitian ini meruakan penelitian kualitatif dengan menggunakan metoda studi kasus. Tujuan dari penelitian ini adalah untuk mengetahui peran perempuan dalam membagi waktu antara sebagai ibu rumah tangga dan bekerja sebagai buruh harian lepas dan untuk mengetahui tingkat kesejahteraan keluarga dari perempuan yang bekerja sebagai buruh harian lepas. Subjek dari penelitian ini adlaah sebanyak ima orang informan dan objeknya adalah perempuan yang bekerja sebagai buruh harian lepas.

Metoda pengumpulan data menggunakan metoda observasi, wawancara mendalam dan dokumentasi. Pedoman wawancara dibuat berdasarkan indikator yang dikeluarkan oleh Badan Kependudukan dan Keluarga Berencana Nasional (BKKBN) terdapat tiga klasifikasi dan 23 indikator. Metoda teknik data menggunakan menurut Miles dan Huberman yaitu pengumpulan data, reduksi data, penyajian data dan simpulan. Untuk keabsahan data menggunakan triangulasi sumber.

\section{Hasil dan pembahasan}

Hasil Penelitian

Kelima informan dimulai dari informan pertama samapai informan keliama dimulai dari Ibu $\mathrm{Ni}$ kadek Ayu Susilawati, Ibu Ni Made Sarini, Ibu Ni Nengah Suami, Ibu Ni Gusti Ketut Widiasih, dan Ibu Ni Wayan Redit bahwa tugas dan tanggung jawab menjadi ibu rumah tangga tetap dilaksanakan meskipun harus membagi waktu dengan bekerja sebagai buruh. Seperti melaksanakan kewajibannya dimulai dari memasak, mencuci, menyiapkan keperluan keluarga, membimbing anak, merawat keluarga jika ada yang sakit dan mematuhi perintah suami. 
Indikator aktualisasi diri pernyataan hasil wawancara dari kelima informan yang memiliki jawaban sama dapat dijelaskan bahwa kondisi keluarga yang setiap hari melaksanakan makan bersama pada saat malam hari dan pada malam hari juga masing-masing keluarga melakukan komunikasi bersama namun dari masingmasing keluarga tidak pernah meluangkan waktu untuk pergi melaksanakan liburan bersama. Selain itu kelima keluarga ini juga tidak memiliki persediaan tabungan untuk keperluan jika ada kebutuhan atau pengeluaran mendadak, ini dikarenakan kondisi keuangan mereka sangat minim dari hasil bekerja sama-sama sebagai buruh harian lepas antara suami dan isteri. Jadi tidak memungkinkan untuk menyisihkan uang untuk menabung, cukup untuk keperluan atau kebutuhan sehari-hari saja sudah sangat mereka syukuri.

Dari pernyataan yang disampaikan oleh kelima informan diatas mengenai perempuan yang bekerja sebagai buruh harian lepas dapat disimpulkan bahwa pengahasilan yang mereka terima sangat membantu untuk kebutuhan keluarga dalam kehidupan sehari-hari. Jika mereka tidak bekerja maka akan kekurangan dalam pemenuhan kebutuhannya, karena penghasilan suami yang bekerja hanya sebagai buruh tidak akan cukup memenuhi kebutuhan keluarganya sendiri. Mengeluh dengan kondisi fisik yang terkadang melelahkan tidak membuat mereka harus berhenti dari pekerjaannya sebagai buruh harian lepas. Buruh sudah bagian dari hidup mereka dan itu sangat menopang kehidupannya demi mencapai kesejahteraan keluarganya. Jadi mereka sudah terbiasa dengan keadaan atau kondisi pekerjaan yang mereka hadapi setiap harinya.

Menurut kelima informan yang menjadi subjek penelitian, keluarga mereka sudah dianggap keluarga sejahtera karena sudah memenuhi kebutuhan sandang, papan, dan pangan sehari-hari, serta mereka dapat memberikan jenjang pendidikan kepada akan-anaknya. Begitu juga dengan ekonomi mereka dari bekerja sebagai buruh harian lepas dapat membantu memenuhi kebutuhan sehari-hari mereka, jadi sangat berpengaruh dalam peningkatan kesejahteraan keluarga.

Pembahasan

Berdasarkan hasil penelitian perempuan yang bekerja sebagai buruh harian lepas yang berada di Desa Tiyingtali menyatakan tidak pernah meninggalkan tugasnya sebagai ibu rumah tangga. Peran utama dalam keluarga terutama dalam mengurus keluarga dan memenuhi segala kebutuhan keluarga adalah kewajiban yang dilaksanakan sebelum pergi bekerja sebagai buruh harian lepas. Pemenuhan kebutuhan dalam keluarga dilihat dari kebutuhan dasar, kebutuhan psikologis, kebutuhan pengembangan dan kebutuhan aktualisasi diri untuk keluarga dari perempuan buruh harian lepas sudah dipenuhi dengan baik dalam menjalankan tugasnya sebagai ibu rumah tangga. Tugas yang dipenuhi oleh ibu rumah tangga dalam keluarga dimulai dari memasak, mencucui, membersihkan lingkungan rumah, membimbing atau mendidik anak, dan melayani suami. Fakih (2005) menyatakan bahwa kodrat wanita pada kenyataannya memiliki peran gender dalam mendidik anak, merawat dan mengelola kebersihan dan keindahan ruamaht tangga.

Perempuan yang berada di Desa Tiyingtali selain berperan diranah domestik sebagai ibu rumah tangga mereka juga berperan diranah publik sebagai pekerja disektor informal yaitu sebagai buruh harian lepas. Sesuai dengan pernyataan Saskara (2011), bahwa perempuan di Bali yang bekerja ikut mencari nafkah mampu meningkatkan ekonomi rumah tangga. Memilih ikut bekerja karena, dorongan untuk meningkatkan pendapatan keluarga dan membantu memenuhi kebutuhan keluarganya demi mencapai keluarga sejahtera. Waktu dan tenaga yang terbagi tidak membuat mereka harus berhenti dalam kontribusinya bekerja sebagai buruh harian lepas, karena pekerjaan yang mereka geluti sekarang sangat membantu untuk memenuhi kebutuhan mereka sehari-hari dan sangat bergantung pada pekerjaan buruh harian lepas. Meningkatnya ekonomi dalam keluarga dengan istri ikut bekerja 
akan dapat mengurangi terjadinya konflik keluarga.

Kontribusi pendapatan istri dengan membantu peningkatan ekonomi rumah tangga secara tidak langsung mampu meningkatkan status sosial keluarga dan perilaku sosial yang lebih baik.

Upah yang diterima oleh perempuan yang bekerja sebagai buruh harian lepas di Desa Tiyingtali sangatlah minim, sehingga dalam keluarga antara suami dan istri yang sama-sama memiliki profesi sebagai buruh harus bekerja ekstra keras agar dapat meningkatkan penghasilannya dan mampu memenuhi kebutuhan keluarganya. Sesuai dengan pernyataan Utama (2020:19), bahwa buruh adalah tenaga kerja yang bekerja pada perusahaan atau orang dengan menerima upah yang relatif kecil. Jadi jika perempuan di Desa Tiyingtali tidak bekerja maka akan kekurangan dalam pemenuhan kebutuhannya. Mengeluh dengan kondisi fisik yang terkadang melelahkan tidak membuat mereka harus berhenti dari pekerjaannya sebagai buruh harian lepas. Buruh sudah bagian dari hidup mereka dan itu sangat menopang kehidupannya demi mencapai kesejahteraan keluarganya. Jadi mereka sudah terbiasa dengan keadaan atau kondisi pekerjaan yang mereka hadapi setiap harinya. Pendidikan yang rendah yang dimiliki oleh perempuan yang ada di Desa Tiyingtali membuat mereka tidak memiliki pilihan lain untuk memilih pekerjaan selain bekerja sebagai buruh harian lepas dimana pekerjaan yang hanya membutuhkan kekuatan fisik saja.

Berdasarkan hasil wawancara terhadap informan dapat disimpulkan bahwa keluarga dari kelima informan dalam penelitian ini sudah bisa dikatakan keluarga yang sejahtera. Keluarga sejahtera dari keluarga perempuan buruh harian lepas ini diliahat dari terpenuhinya kebutuhan seluruh keluarga meliputi kebutuhan sandang yaitu terpenuhinya kebutuhan pakaina, pangan yaitu terpenuhinya kebutuhan makanan dan papan terpenuhinya kebutuhan dengan memiliki tempat tinggal atau rumah. Pemenuhan kebutuhan pendidikan untuk anak-anak mereka juga sudah dilaksanakan dengan baik oleh keluarga perempuan yang bekerja sebagai buruh harian lepas dengan memberikan jenjang pendidikan sampai tingkat SMP dan SMA. Peran sebagai ibu rumah tangga dan bekerja sebagai ibu rumah tangga tidak menghalangi perempuan di Desa Tiyingtali untuk tetap ikut berkontribusi dalam kegiatan aktivitas sosial di masyarakat seperti contohnya melaksanakan ngayah tedun di Banjar mereka. Puspitawati (2012) menyatakan bahwa keluarga sejahtera merupakan keluarga yang mampu memenuhi kebutuhan fisik (makan, minum, pakaian, tempat tinggal), sosial psikologi (pendidikan, pengasuhan terhadap anak, kasih sayang), dan budaya (norma masyarakat, etika kebiasaan, tradisi).

Dilihat dari tahapan keluarga sejahtera berdasarkan indikator yang dikeluarkan oleh Badan Kependudukan dan Keluarga Berencana Nasional (BKKBN) disebutkan bahwa terdapat lima tahapan tingkat kesejahteraan keluarga yaitu; (1) tahapan keluarga pra sejahtera (KPS); (2) tahapan keluarga sejahtera I (KS I); (3) tahapan keluarga sejahtera II (KS II); (4) tahapan keluarga sejahtera III (KS III); (5) tahapan keluarga sejahtera III Plus. Keluarga perempuan buruh harian lepas di Desa Tiyingtali belum bisa mencapai tingkat kesejahteraan keluarga pada tahapan keluarga sejahtera II, keluarga sejahtera III dan keluarga sejahtera III Plus. Dikatakan demikian karena dari indikator pengembangan yang merupakan bagian dari tahapan keluarga sejahtera II masih ada keluarga yang tidak memiliki penghasilan tetap, bekerja sebagai buruh merupakan pekerjaan yang tidak selalu ada untuk mereka, bisa dikatakan pekerjaan musiman. Selain penghasilan tetap terdapat juga pendidikan yang masih kurang dari perempuan buruh harian lepas sebagian besar pendidikannya hanya bisa sampai tingkat SD dan kemampuan memberikan jenjang pendidikan kepada anak-anaknya hanya mampu samapi tingkat SMP dan SMA, karena biaya yang besar mereka tidak mampu memberikan kejenjang yang lebih tinggi, padahal ada harapan besar dari 
mereka untuk memberikannya hingga jenjang perguruan tinggi.

Selanjutnya dilihat dari tahapan keluarga sejahtera III dari indikator aktualisasi diri keluarga perempuan buruh harian lepas belum juga mampu memenuhinya dilihat dari keluarga yang tidak memiliki tabungan untuk persediaan jika ada keperluan yang mendesak. Untuk bisa menabung bagi mereka merupakan tuntutan yang besar, karena mengandalkan bekerja sebagai buruh tidak bisa untuk menyisihkan uang meraka, cukup untuk kebutuhan sehari-hari sudah sangat bersyukur. Selain tabungan mereka juga belum mampu memenuhi kebutuhan dalam bidang meluangkan waktu untuk pergi melaksanakan rekreasi atau liburan bersama keluarga, bahkan dari keluarga perempuan buruh harian lepas sama sekali belum pernah melaksanakan liburan sampai saat ini. Begitu juga pada tahapan keluarga sejahtera III Plus keluarga perempuan buruh harian lepas belum bisa dimasukkan kedalam kategori ini karena belum mampu memenuhi seluruh indikator yang dikeluarkan dari BKKBN.

Namun keluarga dari perempuan buruh harian lepas di Desa Tiyingtali tidak termasuk kedalam tahapan keluarga pra sejahtera, karena tahapan keluarga pra sejahtera merupakan tahapan keluarga yang sama sekali tidak memenuhi indikator dari BKKBN. Jadi dapat disimpulkan bahwa keluarga perempuan yang bekerja sebagai buruh harian lepas di Desa Tiyingtali dapat dinyatakan sebagai keluarga sejahtera dengan tingkat kesejahteraan termasuk kedalam tahapan keluarga sejahtera I, karena terpenuhinya indikator kebutuhan dasar dan kebutuhan psikologis. Selain melakukan wawancara langsung terhadap subjek penelitian mengenai tingkat kesejahteraan keluarga terdapat juga bukti bahwa mereka berada pada tahapan keluarga sejahtera I yang tertera pada data perkembangan desa tahun 2020 yang diperoleh dari kantor Desa Tiyingtali.

\section{Simpulan dan Saran}

Simpulan
Berdasarkan rumusan masalah penelitian dan hasil penelitian dan pembahasan yang telah diuraikan peneliti, maka peneliti dapat menarik kesimpulan yaitu Perempuan yang bekerja sebagai buruh harian lepas yang berada di Desa Tiyingtali dalam membagi waktunya sudah dilaksanakan dengan baik dengan tetap mengutamakan perannya sebagai ibu rumah tangga dalam keluarga dan tetap bekerja sebagai buruh haraian lepas demi menambah pendapatan keluarga dan mencapai kesejahteraan keluarga. Tingkat kesejahteraan keluarga perempuan yang bekerja sebagai buruh harian lepas di Desa Tiyingtali dinyatakan sebagai keluarga sejahtera dan dilihat dari indikator yang dikeluarkan oleh BKKBN termasuk kedalam tahapan keluarga sejahtera I.

Saran

Berdasarkan hasil dari penelitian, adapaun saran yang dapat disampaikan kepada, masyarakat, perempuan dan peneliti. Untuk Masyarakat yang ada di Desa Tiyingtali supaya tidak memandang rendah perempuan terutama laki-laki, kesetaraan gender harus ditingkatkan lagi agar tidak terjadinya diskriminasi terhadap perempuan. Sehingga tingkat pendidikan perempuan bisa disamakan dengan tingkat pendidikan laki-laki, ini bisa mencegah terjadinya pengangguran dan bisa meningkatkan kreativitas perempuan dalam menuntukan pekerjaan untuk membantu kebutuhan keluarga. Masyarakat setempat, diharapakan bisa memberikan dorongan terhadap pekerja buruh harian lepas dan menyediakan pekerjaan yang lebih baik dalam meninngkatkan ekonomi keluarga. Untuk perempuan yang bekerja sebagai buruh harian lepas yang berada di Desa Tiyingtali agar lebih meningkatkan kreativitasnya dalam bekerja, seperti bisa memilih pekerjaan selain menjadi buruh hariann lepas. Berdasarkan hasil penelitian mereka tidak memiliki penghasilan tetap dan tabungan dalam keluarga, jadi harus ekstra dalam bekerja demi memenuh kebutuhan keluarganya begitupun untuk kepala keluarga yaitu para suami dari perempuan buruh harian lepas. 
p-ISSN : 2599-1418

Jurnal Pendidikan Ekonomi Undiksha

e-ISSN : 2599-1426

Vol. 13 No. 2 (2021)

\section{DAFTAR RUJUKAN}

Clara, E. (2020). Sosiologi Keluarga. Jakarta Timur: UNJ PRESS.

Fakih, M. (2005). Analisis Gender \& Transformasi Sosial. Yogyakarta: Pustaka Belajar.

Puspitawati, H. (2012). Gender dan Keluarga Konsep dan Realita di Indonesia. PT. Penerbit IPB Press: Kampus IPB Taman Kencana Bogor.

Puspitawati, H. (2019). Mewujudkan Pendidikan Adil Gender di Keluarga dan Sekolah (Cetakan 1). Bogor: PT. Penerbit IPB Press.

Todaro, M. P., \& Smith, S. C. (2018). Pembangunan Ekonomi. Jakarta: PT Gelora Aksara Pratama.

Yuningsih, Y. (2017). Perlindungan Sosial Pekerja Anak. Yogyakarta: Pandiva Buku. 